\title{
Experimental Determination of Effect of Total Solid (TS) and Volatile Solid (VS) on Biogas Yield
}

\author{
Ejiroghene Kelly Orhorhoro*, Patrick Okechukwu Ebunilo, Godwin Ejuvwedia Sadjere \\ Department of Mechanical Engineering, University of Benin, Benin City, Nigeria

\section{Email address:} \\ kelecom@yahoo.com (E. K. Orhorhoro), ejiroghene.orhorhoro@eng.uniben.edu (E. K. Orhorhoro), \\ patrick.ebunilo@uniben.edu (P. O. Ebunilo),godwin.sadjere@uniben.edu (G. E. Sadjere) \\ ${ }^{*}$ Corresponding author
}

\section{To cite this article:}

Ejiroghene Kelly Orhorhoro, Patrick Okechukwu Ebunilo, Godwin Ejuvwedia Sadjere. Experimental Determination of Effect of Total Solid (TS) and Volatile Solid (VS) on Biogas Yield. American Journal of Modern Energy. Vol. 3, No. 6, 2017, pp. 131-135. doi: 10.11648/j.ajme.20170306.13

Received: October 16, 2017; Accepted: November 3, 2017; Published: November 25, 2017

\begin{abstract}
In this research work, eight different samples of substrates with varying percentage total solid (TS) and volatile solid (VS) were used. The samples which comprises mainly of water hyacinth, waste water (i.e., from ice fish cold room, septic tanks, and abattoir), pig dung, cow dung, corn cobs, potato peels, pineapple peels, rice left over, yam peels, cassava peels, orange peels, sweet potato peels, garri left over, plantain peels, beans waste, banana peels and vegetables, etc., were codigested. In each of the samples, $10 \mathrm{~kg}$ of substrates were used and the experiment was conducted within mesophilic temperature range of $36^{\circ} \mathrm{C}-37^{\circ} \mathrm{C}, \mathrm{pH}$ range of 6.9-7.4 and hydraulic retention time (HRT) of thirty-three (33) days. It was observed that the quantity of biogas yield from these substrates increase with increasing percentage volatile solid and decrease with decreasing percentage volatile solid concentration below and above the optimum value of $91.1 \%(2.88 \mathrm{~kg}) \mathrm{volatile}$ solids which gave the maximum amount of biogas yield for the samples of substrates to be $1.01 \mathrm{~kg}(23.6 \%), 2.01 \mathrm{~kg}(60.75 \%), 2.55 \mathrm{~kg}$ $(84.72 \%), 2.41 \mathrm{~kg}(68.0 \%), 2.35 \mathrm{~kg}(67.67 \%), 1.85 \mathrm{~kg}(59.23 \%), 1.45 \mathrm{~kg}(25.39 \%)$. Furthermore, the results obtained reveal that bio-digesters should be run at $10.16 \%$ total solids, since optimum cumulative biogas generation is achieved at this $\% \mathrm{TS}$ concentration.
\end{abstract}

Keywords: Total Solid (TS), Volatile Solid (VS), Substrates, Mesophilic Temperature, pH Range, Cumulative Biogas Yield

\section{Introduction}

Anaerobic digestion (AD) process also referred to as the biogas process has been widely utilized by the modern society for stabilizing sludge in municipal wastewater treatment plants $[1,2]$. The $\mathrm{AD}$ process is applied as an alternative method for the treatment of animal manure, organic waste from households, urban areas and industries, often associated with energy recovery and the recycling of the nutrients from digested biomass to the agricultural sector $[3,4,5]$. The process is indigenous to natural anaerobic ecosystems and represents the microbiological conversion of organic matter to methane in the absence of oxygen. The digested organic matter resulting from the anaerobic digestion process is usually called digestate [6, 7].
Biogas is produced in different environments such as landfills, sewage sludge and bio-waste digesters during anaerobic degradation of organic matters [8, 9, 10]. Methane is the main component of biogas and is a valuable renewable energy source $[11,12]$. However, methane is a harmful greenhouse gas if emitted into the atmosphere [13]. Methane, upgraded from biogas, can be used for heat and electricity production or as biofuel for vehicles [14, 15]. Biogas contains from $50 \%$ to $70 \%$ methane, $30 \%$ to $45 \%$ carbon (IV) oxide and other gaseous components such as hydrogen sulphide, water vapour, nitrogen, etc. [16]. During the $\mathrm{AD}$ process, the bacteria decompose the organic matter in order to produce the energy necessary for their metabolism. 
The rate of biogas yield and efficiency of the anaerobic digestion process is controlled by the type of substrates being digested, total solid (TS) and volatile solid concentration (VS), temperature ( $\mathrm{T})$, the presence of toxic materials, $\mathrm{pH}$, hydraulic retention time (HRT), solids retention time (SRT), etc. $[17,18]$. Water content is a vital parameter that affects $\mathrm{AD}$ of solid wastes and this is as a result of;

i. Water make possible the movement and growth of bacteria facilitating the dissolution and transport of nutrient and

ii. Water reduces the restriction of mass transfer of particulate substrate.

Total solids (TS) and volatile solids (VS) concentrations of the require substrates provide useful information about biogas yield that can be expected and as well as the process efficiency. Furthermore, mechanical components of AD plant such as pumps and stirrers can only safely process charged substrates with a certain TS concentration. TS is use to describes dry matters of a substrate and it is expressed as the percentage of the total weight in grams per kilogram $[19,20]$. To know the TS of organic matters, the amount of substrate is weighed and dried at $105^{\circ} \mathrm{C}$ until its water content is zero. The weight after drying is divided by the original weight. Paramagurua, et al. [21] reported a drop in biogas production with a continuous increase of TS values, with an optimum biogas production at a TS value of $10 \%$. Other researchers such as Tsunatu, et al. [22] and Budiyono, et al. [23] pointed in same direction. They reported TS of $9 \%$ and $9.2 \%$ for optimum biogas yield respectively. Tsunatu, et al. [22], concluded that increased in TS value brings about drop in water volume which consequently reduce the level of microbial activity, thus, drop in biogas yield.

Volatile solid (VS) concentration is defined as the organic fraction of TS and is commonly measured as a percentage of TS in grams per kilogram. To isolate the inorganic from the organic fraction of the TS, the already dried substrate is burned in a muffle furnace at $600^{\circ} \mathrm{C}$. The residue after incineration is the inorganic fraction. The weight of the dried substrate minus the weight of the inorganic fraction is then divided by the weight of the dried substrate in order to get the VS concentration [20]. VS concentration can be used to assess AD system efficiency. Not only can the biogas potential of a substrate be estimated based on it VS content, but also the degree of degradation can be achieved [22].

\section{Materials and Method}

\subsection{Materials Used}

In this research work, eight different samples of substrates with varying percentage total solid (TS) and volatile solid (VS) were used. The samples which comprises mainly of water hyacinth, waste water (i.e., from ice fish cold room, septic tanks, and abattoir), pig dung, cow dung, corn cobs, potato peels, pineapple peels, rice left over, yam peels, cassava peels, orange peels, sweet potato peels, garri left over, plantain peels, beans waste, and banana peels, vegetables, etc., were co-digested separately. In each of the samples, $10 \mathrm{~kg}$ of substrates were used and the experiment was conducted within mesophilic temperature range of $36^{\circ} \mathrm{C}$ $37^{\circ} \mathrm{C}$, pH range of 6.9-7.4 and hydraulic retention time of thirty-three (33) days. Other materials used in this research work include:
i. Crucible
ii. Laboratory oven
iii. Desiccator
iv. Electronic precision balance
v. Dish tongs
vi. Magnetic stirrer
vii. Wash bottles
vii. Muffle furnace

\subsection{Determination of Total Solid (TS)}

The amount of total solid was determined at Energy Research Centre, University of Benin, Nigeria (Figure 1). It is the amount of solid present in the sample after the loss of water molecules present in it. In other words, is refers to the quantity of the material residue left in the crucible after evaporation of the sample and its subsequent drying in a laboratory oven at $105^{\circ} \mathrm{C}$ for a period of one hour.

These were the procedures followed;

i. A crucible weighing $0.2380 \mathrm{~kg} \mathrm{~kg}$ was properly washed and dried in the laboratory oven at a temperature of $105^{\circ} \mathrm{C}$ for one hour. The crucible was stored and cooled in a desiccator until needed.

ii. The crucible was re-weighed before use $(0.2371 \mathrm{~kg})$

iii. The laboratory oven was switch on and allowed to reach a temperature of $105^{\circ} \mathrm{C}$. This temperature was maintained throughout the experiment

iii. $0.550 \mathrm{~kg}$ of the collected co-digested substrate sample was added to the crucible and diligently placed in the laboratory oven at a temperature of $105^{\circ} \mathrm{C}$. The substrate sample was dried to a constant mass for a period of 1 to 2 hours.

iv. The crucible plus substrate residue were allowed to cool in a desiccator to balance temperature. Desiccators are designed to provide an environment of standard dryness. The desiccator was properly lubricated with grease and this was to prevent moisture from entering the desiccator as the test glassware cools.

v. The crucible plus substrate (material) residue was weighed using electronic precision balance.

Equation (1) was used to calculate the percentage total solids.

$$
\% \mathrm{TS}=\frac{\mathrm{W}_{1}-W_{2}}{W_{3}-W_{2}} \times 100
$$

where,

$\% \mathrm{TS}=$ Percentage total solid

$\mathrm{W}_{1}=$ Weight of dried crucible + dried residue

$\mathrm{W}_{2}=$ Weight of crucible

$\mathrm{W}_{3}=$ Weight of wet sample (substrate) + crucible

Figure 1 shows the experimental setup for determination of percentage total solid. 


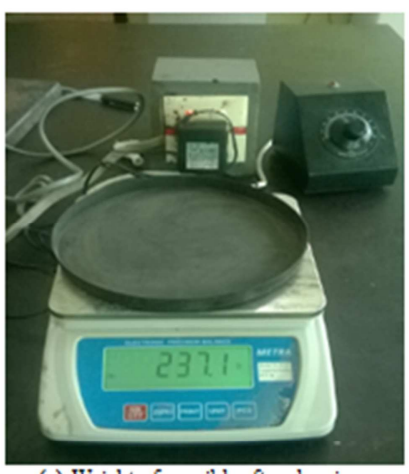

(a) Weight of crucible after cleaning and heating

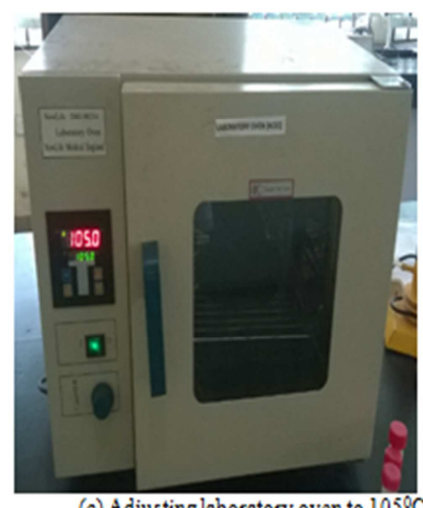

(c) Adjusting laboratory oven to $105^{\circ} \mathrm{C}$

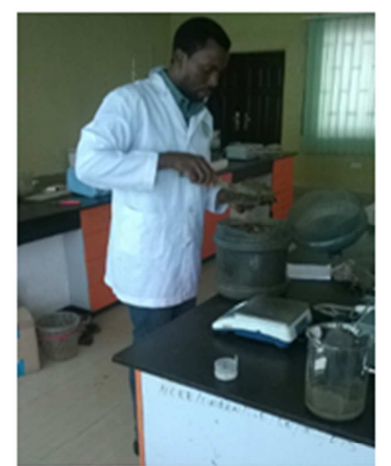

(b) Loading of crucible with substrate

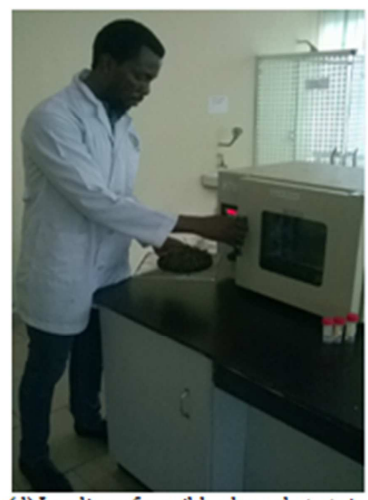

d) Loading of crucible plus substrate in th laboratory oven

Figure 1. Experimental setup for determination of percentage total solid.

\subsection{Determination of Volatile Solid (VS)}

The volatile solid is the solid remaining after evaporation or filtration are dried, weighed, and ignited at $600^{\circ} \mathrm{C}$. The following procedures were followed in determination of the volatile solid of the substrates used.

i. The residue obtained from total solids determination was ignited at $600^{\circ} \mathrm{C}$ for a duration of 30 minutes using a muffle furnace.

ii. The crucible and black mass of carbon were allowed to cool partially in air before it was transferred to the desiccator for complete cooling.

iii. The sample was weighed once temperature balance is reached.

The percentage volatile solid was calculated using Equation (2).

$$
\% \mathrm{VS}=\frac{\mathrm{w}_{1}-W_{4}}{W_{1}-W_{2}} \times 100
$$

where,

$\% \mathrm{VS}=$ Percentage Volatile solid

$\mathrm{W}_{4}=$ Weight of crucible + weight of residue after ignition

Figure 2 shows the experimental setup for determination of percentage total solid.

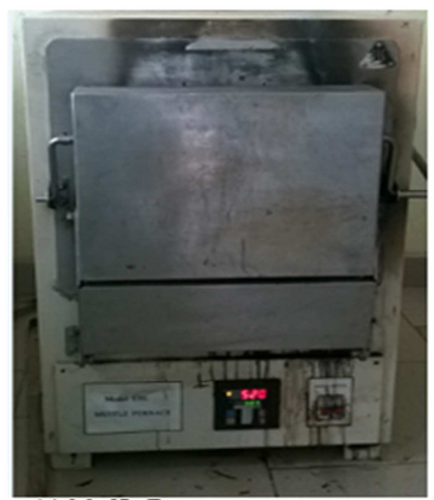

(a) Muffle Fumace

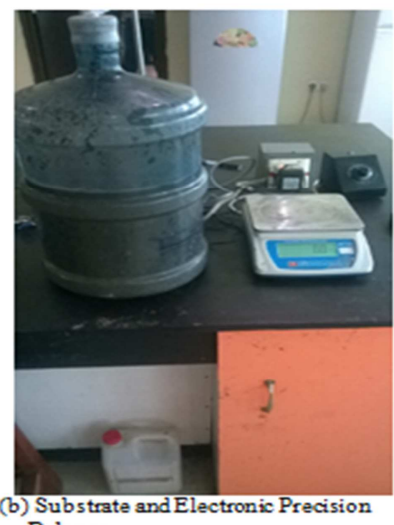
Balance

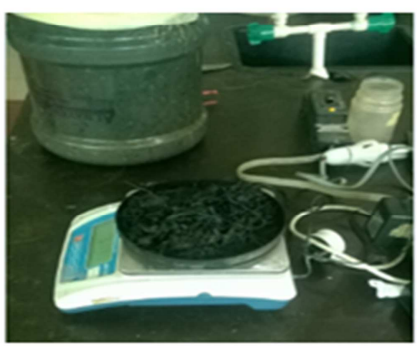

(c) Weighing of crucible plus residu after ignition at $600^{\circ} \mathrm{C}$

Figure 2. Experimental setup for determination of percentage volatile solid.

\section{Results and Discussion}

This research work examined various concentrations of percentage total solid (\%TS) and percentage volatile solid (\%VS) of different substrates composition that were codigested and the corresponding quantities of biogas yield, in order to determine suitable value of $\% \mathrm{TS}$ and $\% \mathrm{VS}$ for optimum biogas production. The outcome of the results obtained from the experiment show that the amount of biogas produced is as a result of the $\% \mathrm{TS}$ and \%VS concentration. There was a gradual increase in biogas yield with a corresponding increase in \%TS and \%VS. However, as the process continue, a time comes when any minimal increase in $\% \mathrm{TS}$ concentration would no longer contribute to the increasing volume of biogas produced (Table 1). Furthermore, our results showed that substrate composition diluted to $10.16 \%$ of total solid content produced optimum cumulative biogas yield (2.88kg) compared to $2.840 \%$ $(1.01 \mathrm{~kg}), \quad 6.840 \% \quad(2.01 \mathrm{~kg}), \quad 9.204 \% \quad(2.55 \mathrm{~kg}), \quad 11.03 \%$ $(2.41 \mathrm{~kg}), 13.74 \%(2.35 \mathrm{~kg}), 17.32 \%(1.85 \mathrm{~kg})$, and $20.52 \% \mathrm{TS}$ $(1.45 \mathrm{~kg})$ [Figure 3]. The results obtained confirm that biodigesters should be run at $10.16 \%$ total solids, since maximum cumulative biogas generation was obtained at this percentage total solid concentration. The results gotten from this research work agree with the work of Paramaguru, et al. [21] that reported TS of $10 \%$ for optimum biogas yield. In same line, Tsunatu, et al. [22] and Budiyono, et al. [19] reported TS of $9 \%$ and $9.1 \%$ for optimum biogas yield respectively. The drop in biogas yield observed in this research work was due to increase in percentage total solid. 
Moreover, it was as a result of decrease in amount of water, which on the other hand reduce the level of microbial activity.

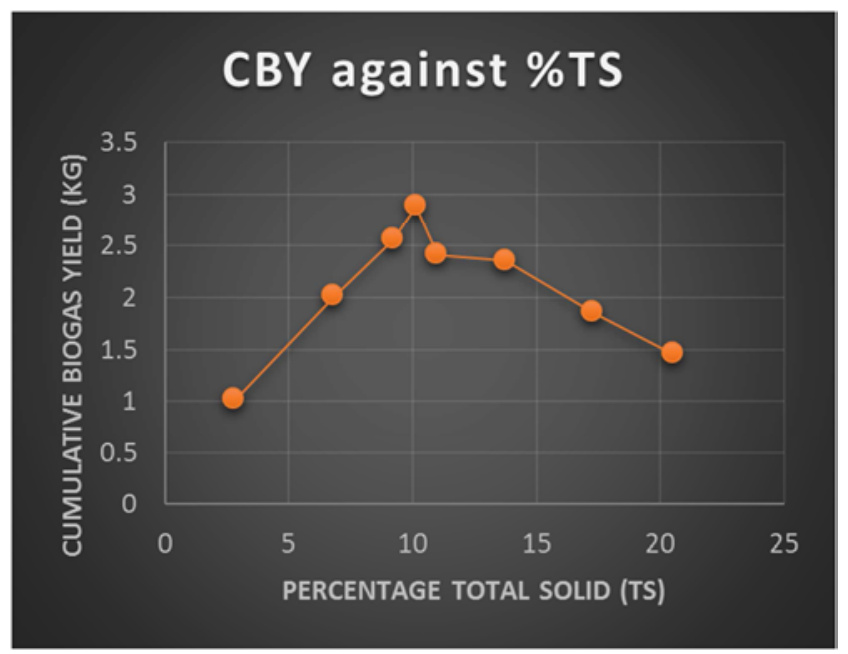

Figure 3. Graph of cumulative biogas yield against percentage total solid.

Also, it was observed from the results obtain with the effect of volatile solid that, the quantity of biogas yield from these substrates increase with increasing percentage volatile solid and decrease with decreasing percentage volatile solid concentration below and above the optimum value of $91.1 \%$ $(2.88 \mathrm{~kg})$ volatile solids which gave the maximum amount of biogas yield for the samples of substrates to be $1.01 \mathrm{~kg}$ $(23.6 \%), \quad 2.01 \mathrm{~kg} \quad(60.75 \%), \quad 2.55 \mathrm{~kg} \quad(84.72 \%), \quad 2.41 \mathrm{~kg}$ $(68.0 \%), \quad 2.35 \mathrm{~kg} \quad(67.67 \%), \quad 1.85 \mathrm{~kg} \quad(59.23 \%), \quad 1.45 \mathrm{~kg}$ $(25.39 \%)$. Figure 4 shows the graph of percentage volatile solid against cumulative biogas yield.

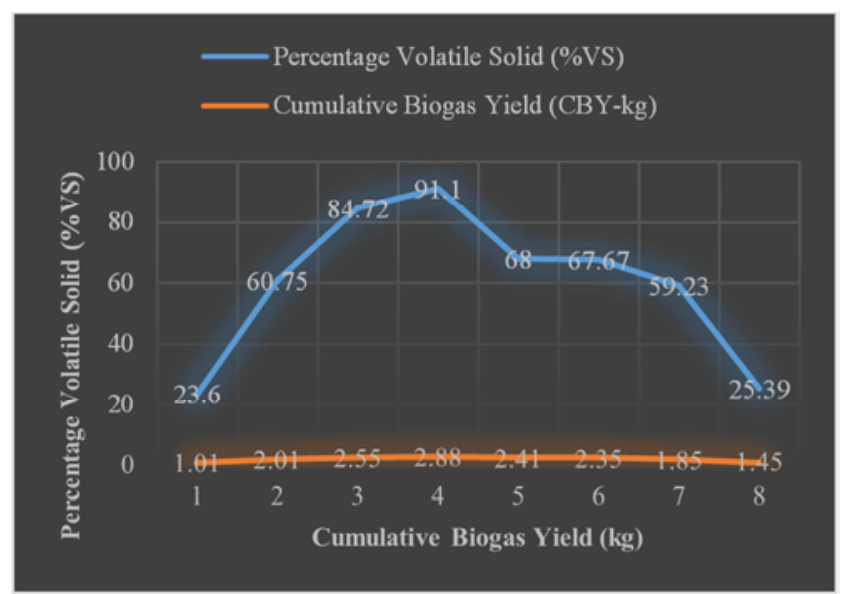

Figure 4. Graph of percentage volatile solid against cumulative biogas yield.

Table 1. Effect of Total Solid (TS) on Biogas Yield.

\begin{tabular}{|c|c|c|c|c|c|c|c|c|}
\hline \multirow{2}{*}{ Substrates } & \multicolumn{3}{|c|}{ Before Drying } & \multicolumn{2}{|c|}{ After drying at $105^{\circ} \mathrm{C}$} & \multirow{2}{*}{ TS (kg) } & \multirow{2}{*}{$\%$ TS } & \multirow{2}{*}{ CBY (kg) } \\
\hline & $\mathrm{W}_{2}(\mathrm{~kg})$ & $\mathrm{W}_{3}(\mathrm{~kg})$ & $\mathrm{W}_{3-} \mathrm{W}_{2}(\mathrm{~kg})$ & $\mathrm{W}_{1}(\mathrm{~kg})$ & $\mathrm{W}_{1-} \mathrm{W}_{2}(\mathrm{~kg})$ & & & \\
\hline Sample 1 & 0.2371 & 0.550 & 0.3129 & 0.2460 & 0.0089 & 0.0284 & 2.840 & 1.01 \\
\hline Sample 2 & 0.2371 & 0.550 & 0.3129 & 0.2585 & 0.0214 & 0.0684 & 6.840 & 2.01 \\
\hline Sample 3 & 0.2371 & 0.550 & 0.3129 & 0.2659 & 0.0288 & 0.0920 & 9.204 & 2.55 \\
\hline Sample 4 & 0.2371 & 0.550 & 0.3129 & 0.2689 & 0.0318 & 0.1016 & 10.16 & 2.88 \\
\hline Sample 5 & 0.2371 & 0.550 & 0.3129 & 0.2801 & 0.0430 & 0.1374 & 13.74 & 2.35 \\
\hline Sample 6 & 0.2371 & 0.550 & 0.3129 & 0.2716 & 0.045 & 0.1103 & 11.03 & 2.41 \\
\hline Sample 8 & 0.2371 & 0.550 & 0.3129 & 0.3013 & 0.0642 & 0.2052 & 20.52 & 1.45 \\
\hline
\end{tabular}

* $\mathrm{W}_{1}$ - Weight of dried crucible and dried residue; $* \mathrm{~W}_{3}$ - Weight of Crucible and wet sample; ${ }^{*} \mathrm{~W}_{2}$ - Weight of Crucible, ${ }^{*} \mathrm{BY}-$ Cumulative biogas yield

Table 2. Effect of Volatile Solid (VS) on Biogas Yield.

\begin{tabular}{|c|c|c|c|c|c|c|c|c|}
\hline Substrates & $W_{1}(\mathrm{~kg})$ & $\mathrm{W}_{2}(\mathrm{~kg})$ & $\mathrm{W}_{1-} \mathrm{W}_{2}(\mathrm{~kg})$ & $\mathrm{W}_{4}(\mathrm{~kg})$ & $W_{1-} W_{4}(\mathrm{~kg})$ & VS & VS (\%) & CBY \\
\hline Sample 1 & 0.2460 & 0.2371 & 0.0089 & 0.2439 & 0.0021 & 0.2360 & 23.60 & 1.01 \\
\hline Sample 2 & 0.2585 & 0.2371 & 0.0214 & 0.2455 & 0.0130 & 0.6075 & 60.75 & 2.01 \\
\hline Sample 3 & 0.2659 & 0.2371 & 0.0288 & 0.2415 & 0.0244 & 0.8472 & 84.72 & 2.55 \\
\hline Sample 4 & 0.2689 & 0.2371 & 0.0318 & 0.2399 & 0.0290 & 0.9119 & 91.10 & 2.88 \\
\hline Sample 5 & 0.2716 & 0.2371 & 0.0450 & 0.2410 & 0.0306 & 0.6800 & 68.00 & 2.41 \\
\hline Sample 6 & 0.2801 & 0.2371 & 0.0430 & 0.2510 & 0.0291 & 0.6767 & 67.67 & 2.35 \\
\hline Sample 7 & 0.2913 & 0.2371 & 0.0542 & 0.2592 & 0.0321 & 0.5923 & 59.23 & 1.85 \\
\hline
\end{tabular}

$* \mathrm{~W}_{4}$-Weight of crucible + Weight of residue after ignition at $600^{\circ} \mathrm{C}$, *VS-Volatile solid, *\%VS-Percentage volatile solid, *BY-Cumulative biogas yield

\section{Summary and Conclusion}

The total solid (TS) and volatile solid (VS) content of substrates affects the performances of anaerobic digestion process. Change in total solids content will lead to change in microbial morphology of $\mathrm{AD}$ systems. Thus, in order to increase the efficiency of anaerobic digestion process, it is paramount for one to understand the role of both total solid and volatile solid content on the behaviour of the microbial activities involved in anaerobic digestion of substrates. In this study, experiment was carried out to determine the effect of total solid (TS) and volatile solid (VS) on biogas yield. The results obtained reveal that bio-digesters should be run at $10.16 \%$ total solids, since maximum biogas generation was obtained at this percentage total solid concentration. The results obtained from the experiment show a significant 
decrease in percentage total solid below the optimum value $(10.16 \%)$. Moreover, biogas production was reduced due to increase in percentage total solid above 10.16. Also, increase in percentage volatile solid resulted to higher quantities of cumulative biogas generated. Therefore, for optimum biogas yield, percentage total solid of $10.16 \%$ is recommended.

\section{References}

[1] E. K. Orhorhoro, P. O. Ebunilo, R. I. Tamuno, I. A. Essienubong. "The Study of Anaerobic Co-Digestion of NonUniform Multiple Feed Stock Availability and Composition in Nigeria", European Journal of Engineering Research and Science, Vol. 1, issue 1, 39-42, 2016.

[2] J. I. Nwankwo. "Production of Biogas from Paper Waste Blended with Cow Dung”, Journal of Environmental Science, Toxicology and Food Technology (IOSR-JESTFT) Volume 8, issue 10, 58-68, 2014.

[3] A. M. Muzaffar, H. Athar, V. Chanchal. "Design considerations and operational performance of anaerobic digester: A review", Cogent Engineering, 3: 118169, 1-20, 2016.

[4] J. C. Motte, R. Escudié, N. Bernet, J. P. Delgenes, J. P. Steyer, C. Dumas. "Dynamic effect of total solid content, low substrate/inoculum ratio and particle size on solid-state anaerobic digestion". Bioresour. Technol., 144, 141-148, 2013.

[5] E. K. Orhorhoro, P. O. Ebunilo, E. G. Sadjere. "Design of BioWaste Grinding Machine for Anaerobic Digestion (AD) System", European Journal of Advances in Engineering and Technology, 4 (7): 560-568, 2017.

[6] O. O. Osita, U. G. Lawan, "The Optimum Mesophilic Temperature of Batch Process Biogas Production from Animal-based Wastes", Research Journal of Applied Sciences, Engineering and Technology, 8(16),. 1772-1776, 2014.

[7] E. K. Orhorhoro, O. W. Orhorhoro, P. O. Ebunilo. "Analysis of the effect of carbon/nitrogen $(\mathrm{C} / \mathrm{N})$ ratio on the performance of biogas yields for non-uniform multiple feed stock availability and composition in Nigeria", International Journal of Innovative Science, Engineering and Technology, Vol. 3, issue 5, 119-126, 2016.

[8] M. K. Peter, M. I. Alfa, G. Datau, K. C. Aluwong, K. C. Hadi. "Design, Development and Performance Evaluation of an Anaerobic Plant", American Journal of Engineering Research (AJER), Vol. 6, issue 4, 2320-0936, 2017.

[9] O. P. Karthikeyan, C. Visvanathan. "Bio-energy recovery from high-solid organic substrates by dry anaerobic bio-conversion processes: a review". Rev. Env. Sci. Biotechnol., 12, 257-284, 2012.

[10] E. K. Orhorhoro, P. O. Ebunilo, A. E. Ikpe. "Effect of pH on Anaerobic Digestion (AD) of Organic Municipal Solid Waste in Benin City, Nigeria", Journal of the Nigerian Association of Mathematical Physics. Volume 36, No.1, 369-374, 2016.
[11] W. Mussoline, G. Esposito, P. Lens, G. Garuti, A. Giordano. "Design considerations for a farm-scale biogas plant based on pilot-scale anaerobic digesters loaded with rice straw and piggery wastewater", Biomass. Bioenerg., 46, 469-478, 2012

[12] P. O. Ebunilo, E. K. Orhorhoro, O. A. Adegbayi. "Investigation of the purification of biogas from domestic wastes using local materials in Nigeria", International Journal of Scientific \& Engineering Research, Volume 7, Issue 2, 505$515,2016$.

[13] S. Desal, V. Palled, R. Mathad. "Performance Evaluation of Fixed Dome Type biogas plant for solid state digestion of cattle dung". Karnataka Journal of Agricultural Science, Vol. 26, No. 1, 103-106, 2013

[14] C. M. Chima, N. O. Jude, C. O. Justina, S. A. Ekpewerechi, "Biogas potential of organic waste in Nigeria". Journal of Urban and Environmental Engineering, Vol. 7, No. 1, 110-116, 2013.

[15] R. Chandra, H. Takeuch. "Methane production from lignocellulosic agricultural crop wastes: A review in context to second generation of biofuel production". Renewable and Sustainable Energy Reviews, 16(3), 1462-147, 2012.

[16] P. O. Ebunilo, S. A. Aliu, E. K. Orhorhoro, "Performance Study of a Biogas Pilot Plant using Domestic Wastes from Benin Metropolis". International Journal of Thermal \& Environmental Engineering volume 10, No 2, 135-141, 2015.

[17] P. O. Ebunilo, S. A. Aliu, E. K. Orhorhoro, "Comparative Analysis of Biogas Yield from Different Composition of Domestic Wastes from Benin City, Nigeria". Journal of Advanced \&Applied Science (JAAS) Volume 04, Issue 05, 169-177, 2015.

[18] A. Alli, L. Rundong, F. Shah, R. B. Mahar, M. S. Wajidljaz, M. Muhammad. "Predictive Modeling of Biogas Production from Anaerobic Digestion of Mixed Kitchen Waste at Mesophilic Temperature". International Journal of Waste Resources, Volume 6, Issue 3, 2-4, 2016.

[19] I. Budiyono, S. S. Syaichurrozi, "Effect of Total Solid Content to Biogas Production Rate from Vinasse", International Journal of Engineering, Vol. 27, No. 2, 177-184, 2014.

[20] N. H. S. Ray, M. K. Mohanty, R. C. Mohanty, "Anaerobic digestion of kitchen waste: Biogas production and pretreatment waste, a review". International Journal of Scientific and Research Publication, 3, 11-18, 2013.

[21] B. B. Sajeena, P. P. Jose, G. Madhu, "Effect of Total Solid Concentration on Anaerobic Digestion of the Organic Fraction of Municipal Solid Waste". International Journal of Scientific and Research Publications, 3(8), 1-5, 2013.

[22] D. Y. Tsunatu, I. C. Azuaga, J. Agabison. "Evaluation of the Effect of Total Solids Concentration on Biogas Yields of Agricultural Wastes". International Research Journal of Environment Sciences, Vol. 3(2), 70-75, 2014.

[23] L. H. Wang, Q. Wang, W. Cai, X. Sun, "Influence of mixing proportion on the solid-state anaerobic codigestion of distiller's grains and food waste", Biosystem Engineering, 112, 130-137, 2012. 